\title{
SUSTAINABILITY REPORTING SEBAGAI MEDIA PERUSAHAAN DALAM MENGEMBANGKAN DAN MELAPORKAN KEBIJAKAN BISNIS BERKELANJUTAN
}

\author{
Satia Nur Maharani \\ Email : tiamaharani@ymail.com
}

\begin{abstract}
Suistainability is about long-term value creation not only for company but also for employees, customers, the industry sector, investors and the communities where the company does business. The ability of company to create long-term value is based on its understanding of and response to demands of society and on recognizing that environtmental, social, economical and ethical factors affect the bussines strategy.This article identifies drives for organitation to adopt corporate social responcibility and produce corporate suistainability report.
\end{abstract}

Key words: Corporate Social Responsibility, Suistainability Reporting

\section{PENDAHULUAN}

Perkembangan ilmu ekonomi sangat dipengaruhi oleh stake holder dalam hal ini perusahaan, lembaga keuangan, intitusi pemerintah, dan masyarakat. Universitas sebagai lembaga pencetak sumber daya insani harus menyadari berbagai perkembangan di luar kampus khususnya pemenuhan kebutuhan stake holder. Diharapkan universitas dapat mencetak tenaga-tenaga masa depan yang memiliki keahlian baik kedalaman ilmu pengetahuan dan ketrampilan sesuai dengan perkembangan yang dituntut oleh stake holder. Sejak 10 tahun terakhir perkembangan ilmu ekonomi baik dalam epistimologis dan ontologis semakin berkembang pesat. Akademisi dan praktisi ekonomi dituntut untuk lebih perduli terhadap tanggung jawab sosial dan lingkungan karena ditangan mereka segala kebijakan ekonomis diambil. Mindset atau cara pandang bahwa perusahaan harus mengedepankan profit oriented mulai banyak dipertanyakan setelah terjadinya berbagai kerusakan baik sosial mapun lingkungan sebagai impact dari aktivitas entitas bisnis dalam meraih profit. Kerusakan hutan lewat penebangan liar, eksplorasi minyak bumi dan batu bara, kerusakan cagar budaya oleh industri pariwisata akibat didirikannya pusat-pusat wisata tanpa memperdulikan aspek sosial masyarakat, kerusakan sosial akibat produk industri hiburan yang tidak peduli dengan etika, dan masih banyak lagi semakin dihubungkan oleh kinerja manajemen masing-masing entitas bisnis. Isu lingkungan secara luas seperti pemanasan bumi, ancaman terhadap lapisan ozon, lahan pertanian yang tidak efisien, permukaan laut semakin naik dan sebagainya membawa konsekuensi tersendiri bagi entitas bisnis khususnya yang high impact untuk lebih bertanggung

Satia Nur Maharani, adalah Dosen Fakultas Ekonomi Universitas Negeri Malang 
jawab tidak hanya dalam jangka pendek melainkan juga masa depan dan harus dituangkan dalam perencanaan bisnis. Pendek kata, perubahan paradigma berfikir bahwa bisnis adalah untuk maksimalisasi keuntungan harus dirubah. Inilah yang dibahas dalam Corporate Sustainability Management (CSM) yaitu organisasi bisnis baik manufaktur dan jasa milik pemerintah maupun swasta dalam merencanakan dan melaksanakan kebijakannya harus berorientasi pada aspek sosial dan lingkungan bukan semata-mata keuntungan untuk kelangsungan generasi sekarang dan masa yang akan datang. Pembangunan yang dilakukan oleh pemerintah, industri bisnis, masyarakat dan non-govermental organization (NGO) untuk memenuhi kebutuhan hidup manusia sekarang tidak boleh mengganggu kemampuan generasi mendatang dalam memenuhi kebutuhan hidup mereka atau disebut sebagai sustainable development. Oleh karena itu, universitas sebagai ujung tombak pencetak tenaga terampil dituntut membekali mahasiswa ekonomi baik jurusan akuntansi, manajemen, dan ekonomi pembangunan untuk perduli terhadap lingkungan alam dan social. Worldview oportunis dan materialis diubah menjadi paradigma yang lebih humanis dan transedental serta peka terhadap lingkungan sosial dan alam.

\section{TINJAUAN PUSTAKA}

\section{Corporate Social Responcibility (CSR)}

Penerapan pembangunan yang berkelanjutan atau suistainable development dari perspektif dunia usaha disebut sebagai Corporate sustainability atau Corporate Social Responsibility (CSR). CSR pertama kali dikembangkan di Inggris sejak 34 tahun yang lalu dan mulai dipopulerkan di Indonesia sejak tahun 2001. CSR adalah kesadaran organisasi bisnis untuk perduli terhadap kepentingan diluar stakeholder internal (share holder, manajemen, dll) dengan menerapkan kebijakan yang ramah terhadap alam dan sosial atau seimbang antara kepentingan organisasi bisnis dengan lingkungan diluar organisasi meskipun tidak diatur dalam legal formal atau UU (bersifat sukarela). Lebih jauh menurut Daniri (2008) CSR dapat dimaknai sebagai komitmen dalam menjalankan bisnis dengan memperhatikan aspek social, norma dan etika bukan saja pada lingkungan sekitar tetapi juga pada lingkup internal dan eksternal yang lebih luas. Keuntungan tidak saja didefinisikan sebagai revenue minus cost melainkan lebih luas lagi bahwa keuntungan mencakup kesimbangan alam, peningkatan kesejahteraan sosial dan harmonisasi antara organisasi bisnis dengan masyarakat. Beberapa alasan kuat mengapa CSR dirasakan semakin perlu untuk diimplementasikan secara konkrit khususnya perusahaan yang memiliki dampak besar terhadap alam dan social adalah sebagai berikut, pertama, untuk menunjukkan kepedulian organisasi bisnis terhadap masyarakat dan lingkungan. Kedua, stakeholder eksternal semakin kaya pemikiran dalam menetapkan kepercayaan kepada perusahaan baik dalam hal produk maupun kinerja secara keseluruhan serta kekuatan komunikasi yang dibangun oleh perusahaan dengan stakeholder eksternal sangat dipengaruhi oleh kepedulain perusahaan untuk mengakomodasi kepentingan mereka. Ketiga, reputasi atau nama baik perusahaan tidak hanya berdasarkan kemampuan dalam menghasilkan laba dan produk yang berkualitas melainkan juga kepedulian 
perusahaan terhadap lingkungan alam dan social bahakan investor untuk mengambil keputusan investasi tidak lagi terpusat pada analisis yang bersifat tekhnikal melainkan juga fundamental secara luas yaitu kepedulian perusahaan untuk menerapkan CSR. Keempat, dengan menerapkan CSR, perusahaan memiliki kemampuan bersaing lebih tinggi karena memiliki kualitas sumber daya manusia yang mumpuni dan teknologi ramah lingkungan serta menguatkan pasar melalui hubungan yang solid dengan pelanggan, supplier, masyarakat, LSM, dan lembagalembaga keuangan penunjang. Suta (2008) menjelaskan CSR adalah part of strategy dari perusahaan untuk membangun reputasi, karena reputasi merupakan intangible asset yang penting. Lebih lanjut Suta menjelaskan hasil penelitian menunjukkan $65 \%$ perusahaan public yang diambil dari kelompok LQ45 menanggap CSR merupakan komponen penting dari reputasi.Manfaat CSR bagi perusahaan dikemukakan pula oleh Suharto (2008) yaitu memperkuat kinerja dan keuntungan ekonomi yang lebih efisien, meningkatkan komitmen para pekerja, memantapkan akuntabilitas perusahaan terkait investasi social dan kemasyarakatan, mengurangi kerentanan dan instabilitas operasi perusahaan terkait menguatnya hubungan dengan masyarakat dan terakhir mempertegas citra dan reputasi perusahaan.

Kepedulian CSR di berbagai belahan dunia semakin meningkat ditunjukkan dengan lebih $79 \%$ dari 1000 CEO di 33 negara menyatakan bahwa CSR merupakan bentuk lain dari profit yang sangat vital bagi perusahaan dan menentukan kemampuan bersaing di pasar. Hal ini ditegaskan oleh Adam dan Zhutshi (2006) "companies that demonstrate social and environtmental impacts gain specific benefits, although not all can be quantified in dollar terms.". Lee (2005; 57) mengutarakan bahwa CSR telah mengalami transformasi dari seuatu yang dianggap beban biaya menjadi sumberdaya yang bernilai tinggi. Lebih lanjut Lee mengajak perusahaan untuk melakukan "resourcification of CSR" sebagai cara untuk mendapatkan manfaat penuh Dario CSR menjadi cara untuk meningkatkan keuntungan ekonomi. Kepedulian lain ditunjukkan oleh konsumen khususnya di negara maju lebih memilih produk yang ramah lingkungan meskipun mengeluarkan uang lebih banyak daripada produk lain yang tidak ramah lingkungan, investor melakukan portofolio investasi pada perusahaan yang menggunakan friendly technology, bank dalam memberikan persetujuan kredit pada perusahaan melaksanakan assessment lingkungan apakah perusahaan tersebut memperhatikan social dan lingkungan dalam aktivitas bisnis mereka (ABN AMRO bank, Manulife, Bank of America, JPMorgan Chase, Rabobank Group, dll.) bahkan New York Stock Exchange menyediakan instrument investasi berupa indeks saham seperti FTSE4Good dan Dow Jones Sustainability Index (DJSI) yang berisikan index saham perusahaan yang telah melaksanakan CSR untuk mengakomodir kepentingan investor yang perduli terhadap CSR.

\section{Suistainability Reporting}

Perkembangan seperti yang telah diuraikan di atas mempengaruhi eksistensi pelaporan keuangan atau yang selama ini dikenal sebagai Accounting Management Report untuk kepentingan pihak internal dan Financial Accounting Report untuk kalangan eksternal. Kuantitative approach yang lebih dipergunakan pada laporan keuangan tidak bisa menampung informasi CSR yang lebih banyak membutuhkan 
kualitatif approach meskipun unsur-unsur materi masih ada. Sebenarnya PSAK sendiri sudah mengatur untuk menyususun laporan tersendiri bagi informasi yang sifatnya sulit diukur atau memerlukan pendekatanan kualitatif sehingga tidak menjadi masalah untuk menyusun laporan yang memuat informasi CSR. PSAK No.1, Paragraph 9 menyatakan bahwa "Perusahaan dapat pula menyajikan laporan tambahan seperti laporan mengenai lingkungan hidup ...., khususnya bagi industri dimana faktor-faktor lingkungan hidup memegang peranan penting...." Selain itu terdapat pula beberapa bidang pelaporan lain yang diatur dalam PSAK seperti PSAK No 33 Akuntansi Pertambangan Umum (1994), PSAK No. 32 Akuntansi Kehutanan (1994), PSAK No. 29 Akuntansi Gas dan Minyak Bumi (1990), PSAK No 45 Pelaporan Keuangan Organisasi Nirlaba (1997), PSAK No 18 Akuntansi Dana Pensiun (1995), PSAK No 24 Imbalan Kerja (2004), PSAK No 57 Kewajiban diestimasi, Kewajiban Kontijensi, dan aktiva kontijensi (2000) dan ISAC No. 3 Interpretasi tentang Perlakukan Akuntansi atas pemberian sumbangan atau bantuan (1997). Perbedaan antara Sustainability Reporting dengan Financial reporting dijelaskan pada tabel 1 di bawah ini (Darwin, 2008):

Tabel 1. Perbedaan Sustainability Reporting dengan Financial reporting

\begin{tabular}{|l|l|l|l|}
\hline & \multicolumn{1}{|c|}{ Produk } & \multicolumn{1}{c|}{ Pedoman } & \multicolumn{1}{c|}{ Referensi } \\
\hline $\begin{array}{l}\text { Financial } \\
\text { Reporting }\end{array}$ & $\begin{array}{l}\text { Balance Sheet } \\
\text { Income Statement }\end{array}$ & $\begin{array}{l}\text { PSAK oleh } \\
\text { IAI }\end{array}$ & $\begin{array}{l}\text { International } \\
\text { Accounting Financial } \\
\text { Standard oleh IFAC }\end{array}$ \\
\hline $\begin{array}{l}\text { Sustainability } \\
\text { Reporting }\end{array}$ & $\begin{array}{l}\text { Ekonomi, } \\
\text { Lingkungan dan } \\
\text { Sosial }\end{array}$ & $\begin{array}{l}\text { Sustainability } \\
\text { Reporting } \\
\text { Guidelines } \\
\text { oleh NCS }\end{array}$ & $\begin{array}{l}\text { Sustainability } \\
\text { Reporting Guidelines } \\
\text { oleh GRI }\end{array}$ \\
\hline
\end{tabular}

Daniri (2009) mengemukakan pentingnya standar atau pedoman umum menerapkan CSR karena adanya ketidak seragaman dalam penerapan CSR di berbagai Negara menimbulkan kecenderungan yang berbeda dalam pelaksanaan CSR yang mempengaruhi laporan CSR. Pada tingkat global, sejak tahun 2002 telah dikembanhgkan bentuk Laporan Keberkelanjutan oleh Global Reporting Initiative. Laporan perusahaan berkaitan dengan kebijakan bisnis yang berorientasi pada CSR disusun dalam Sustainability Reporting berdasarkan Sustainability Reporting Guidelines (RG). RG selama ini merupakan satu-satunya pedoman bagi perusahaan baik dalam dan luar negeri untuk membuat Sustainability Reporting dimana RG ini disusun oleh National Centre for Sustainability Reporting (NSC) dengan referensi dari institusi independen dunia yaitu Global Reporting Initiative yang berkedudukan di Belanda. Global Reporting Initiative (GRI) adalah lembaga independen yang didirikan pada tahun 1997 di Boston, AS dengan keanggotaan multi profesional seperti akuntan, pengusaha, investor, organisasi lingkungan hidup, organisasi HAM, lembaga riset dan organisasi buruh berbagai Negara.GRI berdiri karena semakin mendesaknya transparansi pengaruh aktivitas bisnis perusahaan baik ekonomi, lingkungan dan sosial sehingga dibutuhkan pedoman atau framework untuk menyusun suistainability report bagi perusahaan dalam berbagai ukuran dan sector usaha di seluruh dunia. Tujuannya antara lain meningkatkan harmonisasi perusahaan terhadap stakeholder baik itu shareholder, 
manajemen, karyawan atau buruh, investor, pemerintah, organisasi non pemerintah, masyarakat, membantu investor memiliki analisis secara utuh baik teknikal maupun fundamental dalam menagmbil keputusan investasi, dan lain-lain. Dengan menyusun Suistainability Reporting maka pemakai informasi mengetahui apakah perusahaan transparan dalam menyusun kebijakan yang berorientasi pada lingkungan, stakeholder tidak hanya manajemen, karyawan melainkan juga masyarakat dan alam, pengaruh proses produksi atau aktivitas perusahaan terhadap lingkungan dan sejauh mana perusahaan mengkomunikasikan hal tersebut kepada public dan terakhir apakah perusahaan jujur terhadap diri mereka sendiri dan lingkungan terhadap "impact” perusahaan terhadap lingkungan. Secara garis besar Darwin (2008) menjabarkan beberapa Diagram dibawah ini menjelaskan komponen apa saja yang dilaporkan dalam Sustainability Report berdasarkan Sustainability Reporting Guidelines:

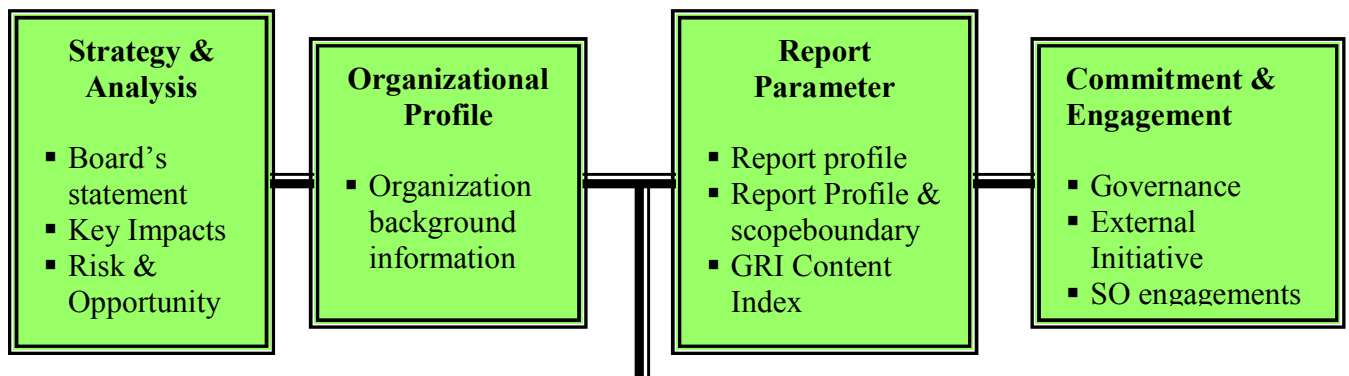

\section{Management Approach \& Performance Indicators}

\begin{tabular}{l}
\hline Economic: \\
Direct economic \\
impacts to : \\
- Customers \\
- Suppliers \\
- Employees \\
- Providers of capital \\
- Public sector \\
\hline
\end{tabular}

\begin{tabular}{|ll||}
\hline Environtmental: \\
- & Materials, Energy, Water \\
- & Biodiversity \\
- & Emissions, Effluents, and waste \\
- & Products and services \\
- & Compliance \\
\hline
\end{tabular}

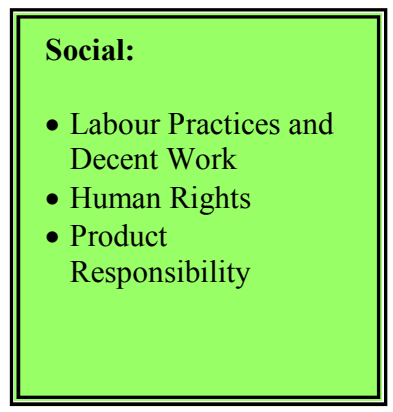

Gambar 1. Sustainability Reporting Guidelines

Komponen yang dilaporkan pada Sustainability Report menurut GRI dapat dijabarkan sebagai berikut, pertama, strategy and Analysis memberikan informasi secara umum strategi perusahaan yang bersifat berkelanjutan. Penjelasan secara terperinci dijelaskan pada bagian lain sehingga tahap ini hanya bersifat umum baik dalam pemberian informasi startegi perusahaan dan inisatif strategis perusahaan yang bersifat susstainability development termasuk pernyataan oleh pengambil keputusan tingkat atas seperti Komisaris Utama, Direktur Utama (CEO), dan 
posisi lain yang setingkat. Selain itu pada bagian ini dijelaskan pula secara naratif pengaruh signifikan suistainability development terhadap stakeholder eksternal (masyarakat, lengkungan alam, dll.), komitmen jangka panjang perusahaan dalam memenuhi tuntutan untuk merencanakan dan menerapkan strategi ekonomis yang bersifat sustainability development sesuai dengan karakteristik usaha untuk meningkatkan kemampuan bersaing, menguatkan pasar, dan menguatkan kepercayaan melalui peningkatan mutu produk yang ramah lingkungan dengan daya pengaruh negatif yang rendah terhadap social masyarakat.Kedua, Organizational Profile memberikan informasi secara menyeluruh mengenai sejarah berdirinya perusahaan, struktur organisasi, lokasi perusahaan, segmen pasar, lingkup perusahaan dalam hal jumlah karyawan,jumlah penjualan dan pendapatan, jenis produk dan kapasitas produksi, total asset, perubahan yang sigifikan dalamjangka waktu periode tertentu misalnya penambahan unit perusahaan karena ekspansi, bertambahnya kepemilikan karena go public,dan sebagainya. Ketiga, Report Parameter pada bagian ini memuat pertama, report profile seperti periode tahun tertentu, laporan tahunan atau tengah tahun. Kedua, report scope and boundary yang memuat lingkup material dan non material, identifikasi stakeholder langsung dan tidak langsung yang berhubungan dengan perusahaan sekaligus pemakai informasi potensial.Ketiga, GRI content index berupa tabel daftar isi kategori laporan untuk memperlihatkan keselarasan laporan dengan GRI serta memudahkan pemakai informasi dalam membaca dan menganalisis informasi yang dilaporkan.Keempat, Governance, Commitments and Engagament. Tahap ini menjelaskan hasil masing-masing departemen atau divisi dalam melaksanakan suistainability development dan program-program yang telah dilaksanakan oleh perusahaan untuk mencegah pengaruh negatif aktivitas bisnis mereka sebagai komitmen perusahaan dalam melaksanakan CSR. Kelima, Management Apparoach and Performance Indicators. Tahap ini merupakan substansi dari pelaporan Sustainability Reporting dimana melaporkan secara terperinci kebijakan perusahaan beserta hasil yang telah dicapai dalam menerapkan CSR yang terbagi dalam tiga kategori dengan indikator yang berbeda-beda. Berikut ini tabel tiga kategori dan indikator masing-masing:

\section{ECONOMIC PERFORMANCE INDICATOR}

$\approx$ Hasil yang bersifat ekonomis beserta distribusinya kepada pemegang saham dan pemerintah termasuk pendapatan, biaya, modal, dll (laporan keuangan).

$\approx$ Pengaruh keuangan baik positif maupun negatif terhadap organisasi bisnis.

$\approx$ Rencana keuangan kedepan atau periode berikutnya.

$\approx$ Bantuan keuangan yang diterima dari pemerintah.

$\approx$ Gaji yang diterima masing-masing pekerja sesuai fungsi dan tangung jawab dan dibandingkan dengan UMR.

$\approx$ Eksistensi pemasok lokal atau masyarakat dilingkungan sekitar organisasi bisnis

$\approx$ Kebijakan perusahaan merekrut masyarakat sekitar sebagai tenaga kerja. 


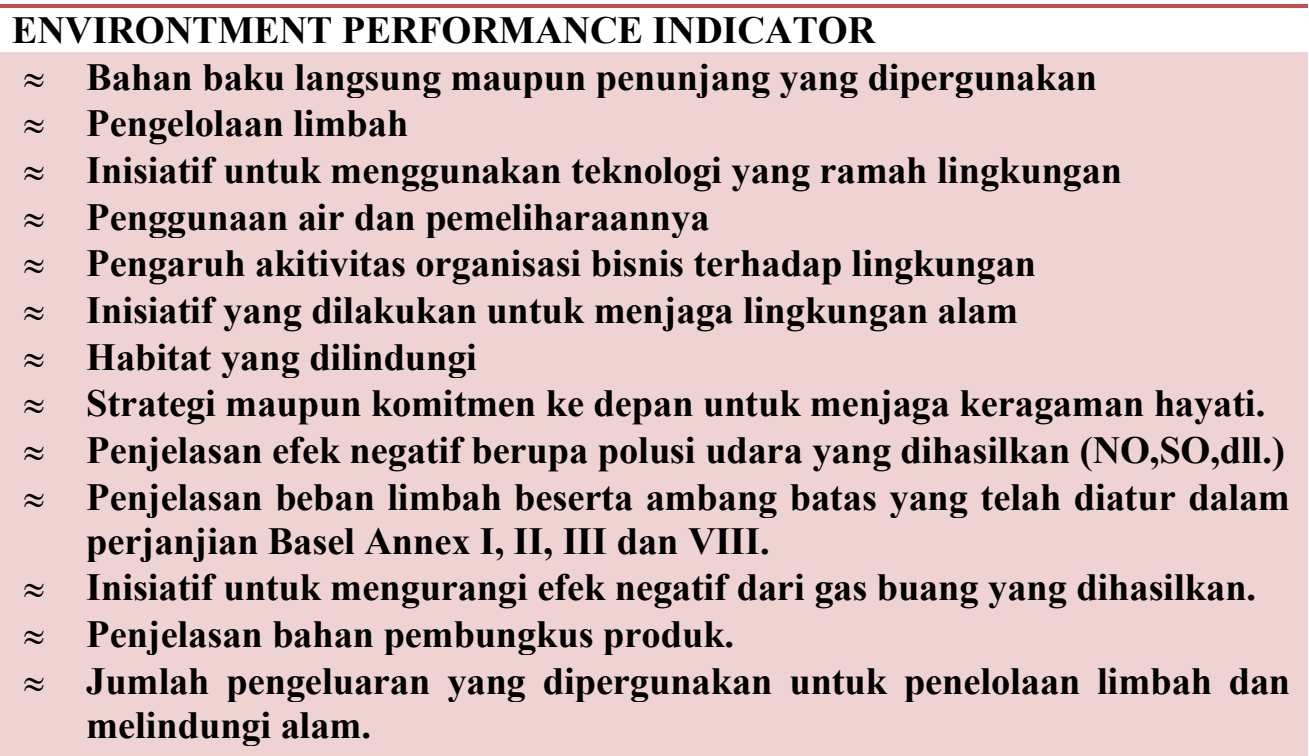

\section{SOCIAL PERFORMANCE INDICATOR}

$\approx$ Jumlah pekerja dari tingkat atas sampai bawah, tugas \&tanggung jawab, jenis kelamin,umur, dll.

$\approx$ Jaminan kesejahteraan bagi karyawan tetap dan tidak tetap

$\approx$ Organisasi karyawan untuk menyalurkan aspirasi karyawan.

$\approx$ Kecelakaan, penyakit dan kematian yang mungkin terjadi dalam melaksanakan tugas.

$\approx$ Pendidikan dan pelatihan bagi karyawan untuk mencegah kecelakaan kerja.

$\approx$ Jam kerja baik sebagai karyawan tetap, kontrak atau yang masih dalam masa training.

$\approx$ Kepedulian perusahaan terhadap hari tua seluruh pekerja.

$\approx$ Perbandingan upah minimum antara pekerja laki-laki dan perempuan sesuai dengan jenis pekerjaan.

Untuk mengetahui bahwa perusahaan memiliki komitmen dan prinsip yang tangguh dalam menjalankan kebijakan yang berorientasi pada CSR, maka diperlukan system yang menjamin seluruh pemangku kepentingan mengetahui dampak perusahaan baik positif maupun negative. Laporan CSR yang disusun dan diterbitkan setiap tahun merupakan salah satu cara untuk mengetahui hal tersebut. Manfaat publikasi laporan CSR menurut Jalal (2008) adalah untuk menjamin dan memastikan bahwa ada sebuah system yang menjamin seluruh pemangku kepentingan mengetahui dampak perusahaan baik positif maupun negative. Lebih lanjut Darwin (2008) menjelaskan fungsi dari laporan CSR adalah untuk menjawab beberapa pertanyaan, pertama, apakah tingkat keterbukaan perusahaan sudah satu level dengan harapan dan permintaan masyarakat? Kedua, apakah perusahaan tahu 
atau sadar siapa pemangku kepentingannya?, Apa hyang menjadi perhatian mereka?Dan bagaimana perusahaan harus menyikapinya? Ketiga, tahu dansadarkah manajemen tentang apa yang dimaksud dengan dampak social dan lingkungan?Apakah manajemen telah berkomunikasi dengan pemangku kepentingan? Bagaimana perusahaan mengambil tanggung jawab atas dampak lingkungan dan social? Keempat, apakah perusahaan sudah melaporkan semua dampak yang berkaitan dengan masalah lingkungan dan pengembangan masyarakat setempat?

\section{PEMBAHASAN}

\section{Aplication Level Criteria}

Seberapa jauh perusahaan dalam menerapkan CSR dapat dinilai melalui informasi yang terkandung di dalam Suistainability Report. Semakin lengkap semua indikator yang ditetapkan Reporting Guidelines (RG) dilaksanakan dan dilaporkan dalam Suistainability Report maka dapat dikatakan perusahaan tersebut semakin menerapkan suistainability development dalam setiap kebijakan bisnis. Selain itu, semakin lengkap indikator dilaksanakan dan dilaporkan maka perusahaan semakin berada di level atau peringkat yang semakin baik. RG selain memberikan pedoman atau petunjuk penyusunan Suistainability Report juga menetapkan peringkat sebagai dasar penilaian pelaksanaan dan pelaporan kebijakan bisnis yang berorientasi pada suistainability development. Selain itu, penetapan peringkat memberikan motivasi bagi perusahaan dalam penyusunan Suistainability Report berikutnya.Adapun peringkat untuk menilai kualitas dari Suistainability Report menurut RG dapat dilihat pada diagram di bawah ini:

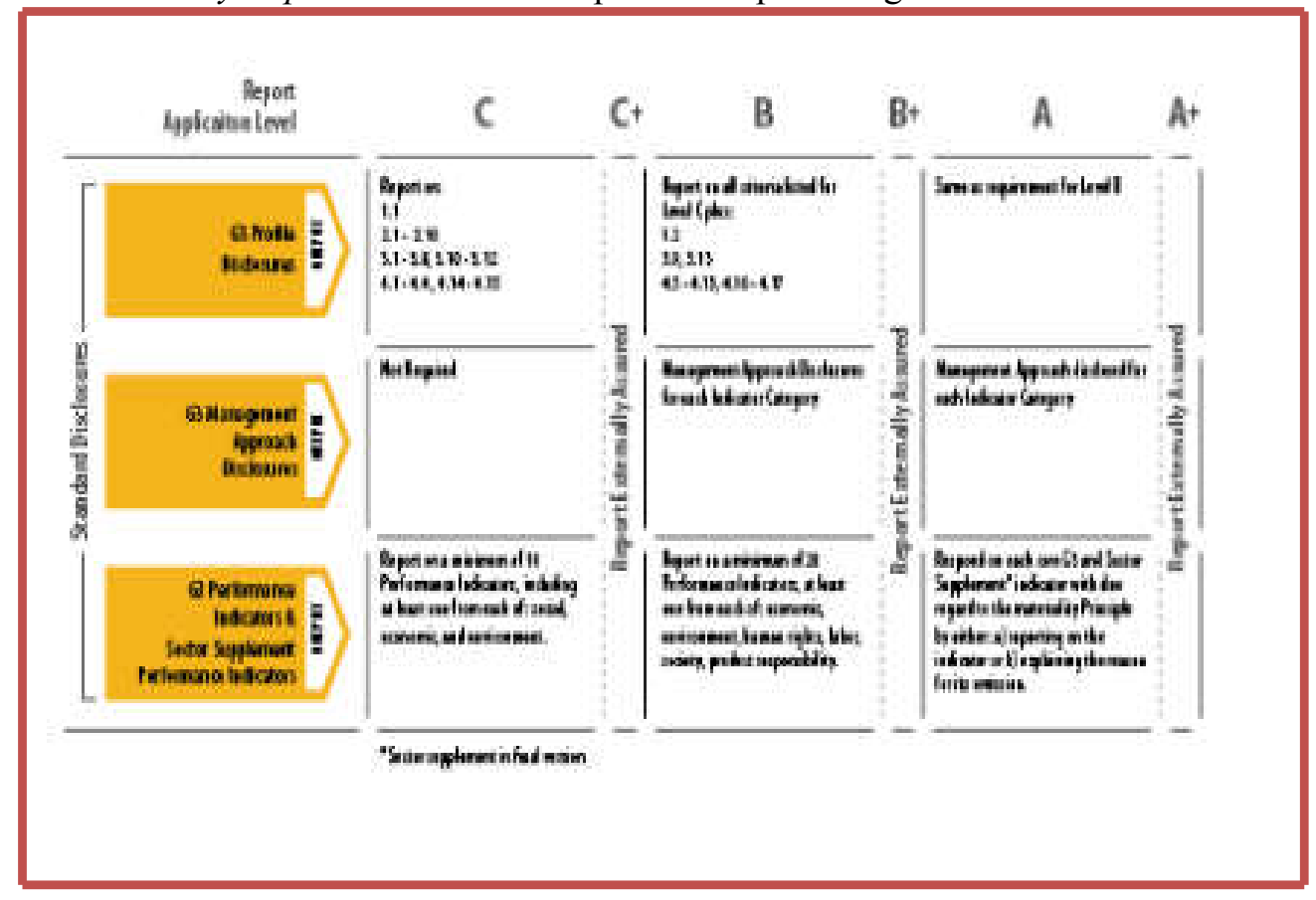


Sustainability Reporting untuk menunjukkan level mana yang diraih oleh perusahaan beserta institusi yang mensahkan peringkat tersebut. Pembuat Sustainability Reporting dalam hal ini eksternal auditor harus menyesuaikan antara peringkat yang diharapkan dan ditetapkan untuk perusahaan dengan seluruh indikator yang dimuat dalam RG.Peringkat tersebut digambarkan dengan penilaian terendah huruf $\mathrm{C}$ sampai yang peringkat maksimal yaitu $\mathrm{A}+$. Semakin tinggi peringkat yang diterima oleh perusahaan maka semakin sempurna pelaksanaan kebijakan bisnis mereka berorientasi pada suistainability development. PT Timah misalnya mengeluarkan laporan keberlanjutan atau Suistainability Reporting dengan Level Criteria B. Hal ini dapat dijelaskan sebagai berikut:

\section{Self Declaration of GRI G3 Application Level by PT Timah (Persero) Tbk GRI Apliccation Level Criteria For}

Reports intended to quality for level $\mathrm{C}, \mathrm{C}+, \mathrm{B}, \mathrm{B}+, \mathrm{A}$ or $\mathrm{A}+$ must contain each of the criteria that are presented in the column for the relevant level.

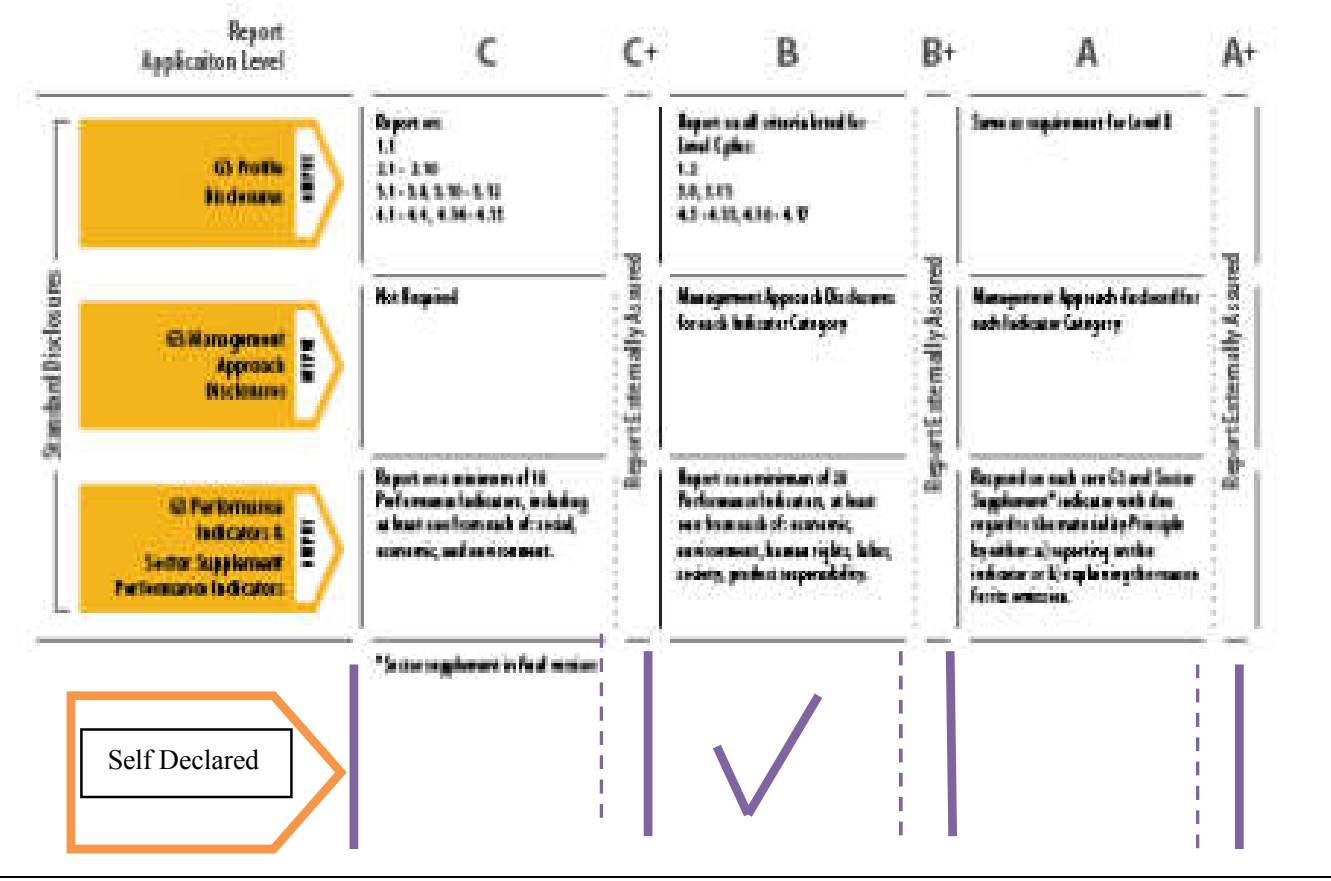

PT. Timah sebagai perusahaan tambang kelas dunia, dituntut bukan saja mampu menghasilkan produk berkualitas dengan standar mutu internasional. Timah juga diharuskan memiliki kebijakan mengelola lingkungan yang dilaksanakan terpadu di semua kegiatan.Tidak sebatas pada saat berlangsungnya kegiatan produksi penambangan, tetapi juga keguiatan-kegiatan lain baik sebelum maupun pasca penambangan. Dalam Laporannya PT Timah masuk dalam level kriteria B dimana pada level tersebut laporan telah memuat aktivitas kebijakan yang berkelanjutan melalui Strategi dan analisis, Profil Organisasi, Parameter Laporan serta komitmen dan Tata Hubungan yang sesuai dengan pendekatan manajemen dan indikator kinerja yang berkelanjutan yang ditetapkan dalam GRI 
G3 berupa kebijakan tentang menejemen lingkungan, keselamatan dan kesehatan kerja, Pengembangan SDM berkelanjutan, Pertambangan Rakyat, pengembangan Masyarakat, Implementasi tata kelola Berkelanjutan dan Kinerja Ekonomi yang berkelanjutan. Untuk menjaga konsistensi penerapan kebijakan yang berkelanjutan maka PT Timah secara periodik mengeluarkan laporan Suistainabilty Reporting sehingga setiap manajemen dituntut untuk bertanggung jawab meningkatkan kepedulian dan menjaga kesadaran serta kepatuhan semua karyawan. Manajemen juga memastikan seluruh jajaran perusahaan menerima tanggung jawab bersama, atas penerapan kebijakan pelestarian lingkungan yang sudah ditentukan.

Astra merupakan perusahaan pertama di Indonesia yang menyusun Sustainability Report tepatnya dimulai tahun 2004 disusul kemudian Antam, Timah, Telkom, Kaltim Prima Coal dan lain-lain. Total sampai dengan tahun 2008 sudah 20 perusahaan besar di Indonesia menyusun Sustainability Reporting disamping Financial Report. Diharapkan kedepan semakin banyak perusahaan lain yang menyusul sehingga diperoleh keseimbangan antara kinerja ekonomi, lingkungan dan sosial (triple bottom line) untuk mewujudkan sustainability development bagi generasi mendatang. Karena sifat penyusunan Sustainability Reporting adalah sukarela, maka untuk memotivasi perusahaan melakukan corporarate sustainability management diberikan semacam penghargaan bagi perusahaan yang telah melaksanakan CSR dengan baik berupa Indonesia Sustainability Reporting Award sebagai bentuk apresiasi terhadap perusahaan. Namun disadari terdapat kendala dalam menyusun Sustainability Report khususnya pada sumber daya manusia. Profesi akuntan yang tersedia selama ini tidak cukup memiliki keahlian untuk menyusun Sustainability Reporting karena terdapat perbedaan karakteristik mendasar dengan Financial Reporting. Oleh karena itu untuk mendapatkan ijin menyusun Sustainability Report, akademisi yang bergelar akuntan dan praktisi membutuhkan pelatihan spesialisasi tingkat lanjut. Sedangkan pada lingkup universitas, mahasiswa fakultas ekonomi harus dibekali mata kuliah yang terkait dengan CSR. Di beberapa negara maju seperti Amerika dan Belanda, CSR sudah tidak lagi berbentuk mata kuliah melainkan program studi tersendiri baik S1,S2 dan S3, ini membuktikan bahwa pasar sudah tidak mau menunggu lebih lama lagi tersedianya fresh graduate yang paham dengan CSR. Seminar, short course, riset maupun kegiatan ilmiah lain diperlukan bagi peningkatan kualitas mahasiwa untuk memenuhi tuntutan "stakeholder" mereka yaitu perusahaan baik swasta maupun pemerintah. Berikut ini perusahaan yang telah membuat Laporan keberlanjiutan (Suistainability Report) pada tahun 2007:

\begin{tabular}{|l|l|}
\hline \multicolumn{1}{|c|}{ NAMA PERUSAHAAN } & \multicolumn{1}{c|}{ SEKTOR } \\
\hline PT. Kaltim Prima Coal & Pertambangan batubara \\
PT. Astra International Tbk & Otomotif \\
PT. Riau Andalan Pulp \& Paper & Pupl dan Kertas \\
PT. Tambang Batubara Bukit Asam & Pertambangan batubara \\
Tbk & \\
PT. Aneka Tambang Tbk & Pertambangan mas dan logam \\
PT Telkom Indonesia Tbk & Telekomunikasi \\
PT. Timah Tbk & Pertambangan timah \\
PT. International Nickel Indonesia & Pertambangan nikel \\
\hline
\end{tabular}




\begin{tabular}{|l|l|}
\hline Tbk & \\
PT. Kiat Indah Pulp \& paper Tbk & Pulp dan Kertas \\
\hline PT. Unilever Indonesia Tbk & Produk konsumer \\
PT. Medco Energi International Tbk & Minyak dan gas \\
\hline PT. Pembangunan Jaya Ancol Tbk & Properti \\
\hline
\end{tabular}

\section{KESIMPULAN}

Kepedulian entitas bisnis diimplementasikan dalam Corporate Social Responsibility (CSR). Menurut the Worl Business Council for Suistainable Developo ment (WBCSD), CSR diartikan sebagai"... business comitment to contribute to suistainable economic development, working with employees, their families, the local community, and society at lerge to improve their quality of life..". Dengan melaksanakan CSR akan diperoleh keseimbangan antara kinerja ekonomi, lingkungan dan sosial sebagai syarat menuju suistainability development.

Kebijakan perusahaan yang berkelanjutan pada saat ini sudah menjadi salah satu tolak ukur penting dalam penilaian kinerja perusahaan. Investor dalam mengambil keputusan investasi maupun perbankkan dalam meyalurkan kreditnya tidak lagi hanya menjadikan laba sabagai satu-satunya indikator untuk menilai prospek usaha melainkan juga kepedulian perusahaan pada masyarakat dan alam.Oleh karena itu dalam menuangkan informasi yang lebih banyak bersifat kualitatif perusahaan menyususn Suistainability Reporting berdasarkan Sustainability Reporting Guidelines (RG). RG ini disusun oleh National Centre for Sustainability Reporting (NSC) dengan referensi dari institusi independen dunia yaitu Global Reporting Initiative yang berkedudukan di Belanda. Global Reporting Initiative berdiri karena semakin mendesaknya transparansi pengaruh aktivitas bisnis perusahaan baik ekonomi, lingkungan dan sosial sehingga dibutuhkan pedoman atau framework untuk menyusun suistainability report bagi perusahaan dalam berbagai ukuran dan sector usaha di seluruh dunia. Tujuannya antara lain meningkatkan harmonisasi perusahaan terhadap stakeholder baik itu shareholder, manajemen, karyawan atau buruh, investor, pemerintah, organisasi non pemerintah, masyarakat, membantu investor memiliki analisis secara utuh baik teknikal maupun fundamental dalam menagmbil keputusan investasi, dan lain-lain.

\section{DAFTAR PUSTAKA}

Adams, Carol dan Zutshi, Ambika, 2006, Why Businesses Should Act Responsibly and Be Accountable, Accountants Today Vol 32, pp. 25 - 28

Darwin, 2008, Membuat Laporan Bohong Nama Baik Akan Hancur, Majalah Bisnis \& CSR Reference For Decision Maker, Vol. 1,No. 6, pp. 18 - 33

,2008, Corporate Sustainability /Corporate Social Responsibility ( C S R), Training for Trainers on Corporate Sustainability Management Course 11 - 13 November, Universitas Indonesia, Jakarta. 
Daniri,A. Mas, 2008, Standarisasi CSR, Majalah Bisnis \& CSR Reference For Decision Maker, Vol. 1,No. 6, pp. $52-61$

Jalal, 2008, Membedah Laporan CSR., Majalah Bisnis \& CSR Reference For Decision Maker, Vol. 1,No. 6, pp. $80-99$

Lee, P. Min-Dong, 2005, Review of Theories of Corporate Social Responcibility: Its Evolutionary Path and the Road A Head, International journal of Management Reviews Vol. 10/1, pp. 53 - 73

PT. Timah Tbk., 2007, Laporan Keberlanjutan 2007,Jakarta 